UDC 65.011.56:633.1 (045)

${ }^{1}$ V. M. Sineglazov,

${ }^{2}$ V. S. Ischenko

\title{
OPTIMAL CHOICE OF HARDWARE COMPLEXES OF VISUAL NAVIGATION SYSTEM UAV
}

Aviation Computer-Integrated Complexes Department, National Aviation University, Kyiv, Ukraine E-mails: ${ }^{1}$ svm@nau.edu.ua, ${ }^{2}$ IschenkoVitaly@gmail.com

\begin{abstract}
The design problem of unmanned aerial vehicle visual navigation system is considered. It is proposed the method of technical means selection of visual navigation system based on the use of hierarchies analysis method.
\end{abstract}

Index terms - Visual navigation system; unmanned aerial vehicle; camera; flight controller.

\section{INTRODUCTION}

The problem of high-precision navigation of aircraft without using of any radio signals the last time received high relevance due to active using unmanned aerial vehicles (UAVs) in areas of radio electronic warfare. Visual navigation system helps in cases when there is a probability of GPS signal loss. Often, GPS signal loss cause crash of UAV. Visual navigation system (VNS) allow to reduce the probability of an accident, as UAV can "return to home" or "continue the mission" using only visual objects on the ground. Visual navigation, i.e. orienteering by comparing images taken with specific reference map is a promising way to solve this problem.

Basic components of technology provide a solution for the several tasks:

1. Autonomous navigation with on-the presence or unreliable satellite navigation, availability a lot of information through geophysical fields and so on.

2. Organization of autonomous flight of a single UAV in the absence or non-secure communications with operator, possible changes of the current situation, the state of the UAV, target mission and so on.

3. Organization of autonomous flight Autonomous group (subgroups) with a variety of UAVs (perhaps quickly changeable) targets private, require individual control.

Modern technology of solving navigation tasks by UAV propose the integrated using of inertial, satellite and visual navigation systems.

\section{ANALYZE OF REQUIREMENTS TO FORMULATE THE BASIC STEPS OF SYNTHESIS SYSTEM STRUCTURE}

Figure 1 shows generalized block diagram. Sharper of current images represents by itself device, that converting information sensors field of object - landmark navigation in the form of, convenient for comparison with a reference map of the area stored in the onboard microcomputer. Sharper performs sampling, quantization and scaling signals from field sensor in accordance with the parameters and conditions sightings navigation orienteers: current altitude of flight and viewing angles of the object. Module of estimation location performs following basic operations. As a result of combining by determined algorithm module estimates coordinates of reference point, Calculates value of root mean square trajectory of aircraft flight and transmit estimation to onboard control system, where create a command on correction trajectory of flight UAV. As a similarity of images the most often use cross-correlation function or normalized coefficient correlation. Before the flight the computer system loads a digital map of the area made up of aerial photographs or satellite images of the territory over which the flight will be done. Area map ties predetermined visible landmarks to the their GPS coordinates. During the flight onboard sub-system uses a camera to find these landmarks on the ground. Image processing is performed directly on-board CPU. Once the system has found one or more known reference points it gives estimation of coordinates to navigation system of UAV. Thus, this system "complements" GPS data and corrects navigation of autopilot.

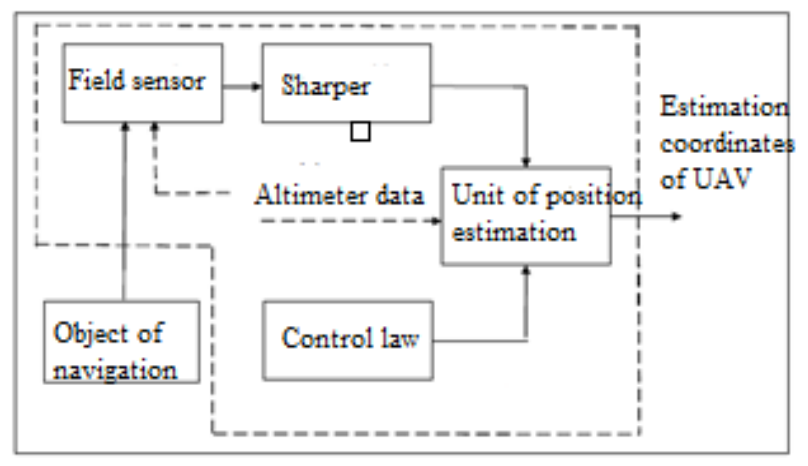

Fig. 1. Generalized block diagram 
The first step is to select the type of the information sensor that meets the requirements for guidance accuracy, all-weather, speed, noise immunity, dimensions and weight characteristics, costs. In the second stage of synthesis of system structure necessary to develop algorithms of processing images and methodology of synthesis corresponding to these algorithms, satisfying the requirements of the synthesis efficiency and renovation system for different conditions of flight UAV (Fig. 2). Third stage of system synthesis consist of processing the results of the first and second stages, as well as requirements for information processing speed and reliability of the system in general. To this or that kind of information field could be used by system, it must meet a number of requirements:

- be stable in time;

- make it possible to measure the parameters accurately relatively simple sensors;

- be well-known, and provide the ability to simply receive reference maps;

- have a pronounced dependence of the parameters of the location.

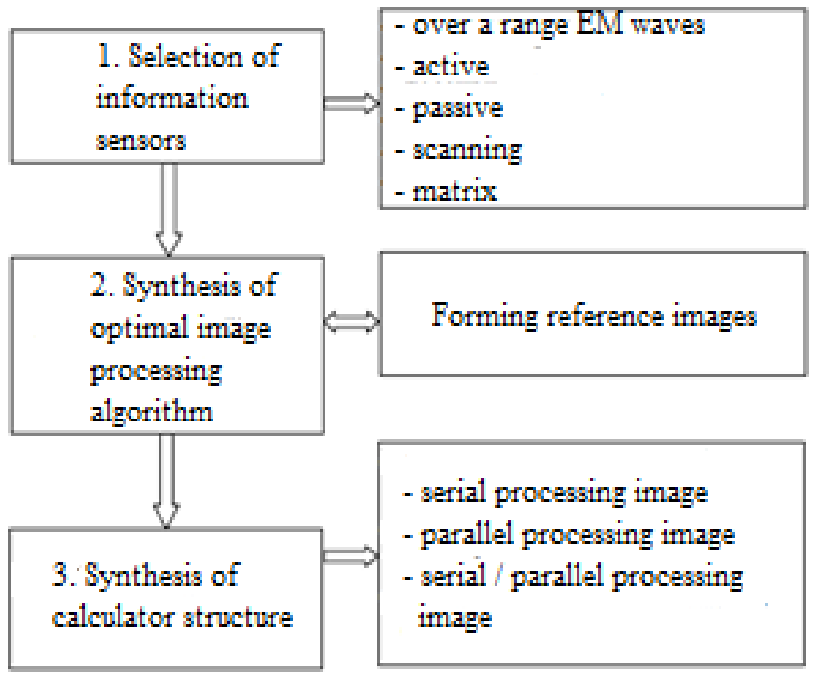

Fig. 2. Analyze of requirements to formulate the basic steps of synthesis system structure

The problems of the system:

1. The variability of the conditions of observation.

2. Few informative fields.

Identification of images of different ranges and other.

\section{THE STRUCTURE OF VISUAL NAVIGATION SYSTEM}

Setting choice problem of the technical means for VNS (Fig. 3).

From the block diagram it is clear that the necessary range of SVN components include: autopilot, on-board microcomputer, a battery for their autonomous power and camera.

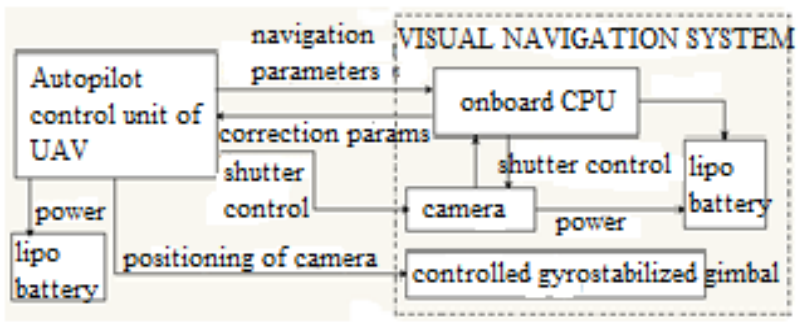

Fig. 3. Structure of visual navigation system

Many visual navigation systems have on-board computer and simply send captured images to the ground station, where the powerful and the overall calculators perform image processing and navigation of UAVs. But this method does not provide for the implementation of the main tasks of navigation, namely, flight in radio electronic warfare zone in the presence of noise. In this case, data link to a ground station is not operable and the system does not work. Our model of SVN is built on the principle of performing all calculations autonomously on board the UAV.

Limiting weight and computing power onboard the UAV equipment causing the difficulty of choosing someone components for SVN.

Weight and power the onboard computer that performs image processing and pattern recognition targets are limited and its parameters directly affect the selected camera specifications. Since the camera images can be by width and height such high resolution that the onboard computer will not have enough processor time to process them. On the other hand if the images from the camera are too noisy and blurred the processing and recognition algorithms of onboard computer will work very bad.

Is necessary select the autopilot, onboard microcomputer and a camera on the optimum ratio. The technical specifications of camera camera should allow to make high-quality images, but just enough so that on-board microcomputer time to process them and have the highest possible computational abilities. Autopilot, in turn, should provide functionality for gimbal control, ability of integration with SVN, simplicity of data exchange with SVN and must have auto mode to fly by navigation points.

The fulfillment of these conditions contributes to the dismemberment of the above mentioned shell construction into separate compartments.

Particular attention is paid to the possibility of carrying out control checks and replacement of equipment, which is achieved by the presence of performance hatches and connectors, as well as 
modernization or changing of the functional capabilities of the equipment. These requirements are particularly well satisfied with the modular building construction, when replacing a unit or shell compartment with its integrated equipment allows the UAV to give new quality without changing the basic design solutions. This modular design principle of the UAV is quite advanced as it provides opportunities for the modernization of the UAV and expanded it range of use.

In addition to the navigation and control of the $\mathrm{UAV}$, autopilot is programmed to control the onboard equipment:

- camera stabillization;

- synchronized in time and by coordinates operation of the camera shutter.

Since the main direction chosen for the development of the UAV, is to find a technical compromise between reducing its dimension and weight and improve overall performance functionality at the cost of restrictions on the development of production and operation, remain relevant selection criteria instrumentation UAVs, namely: cost, size, precision.

\section{OVERVIEW OF OPTICAL DEVICES}

Optical sensors and cameras are very different in size, weight and functionality. Obviously, implementation of such specific requirements as to the distance of the subject and allowing high capacity per area inevitably increases the weight and cost of such devices (Figs 4 and 5).

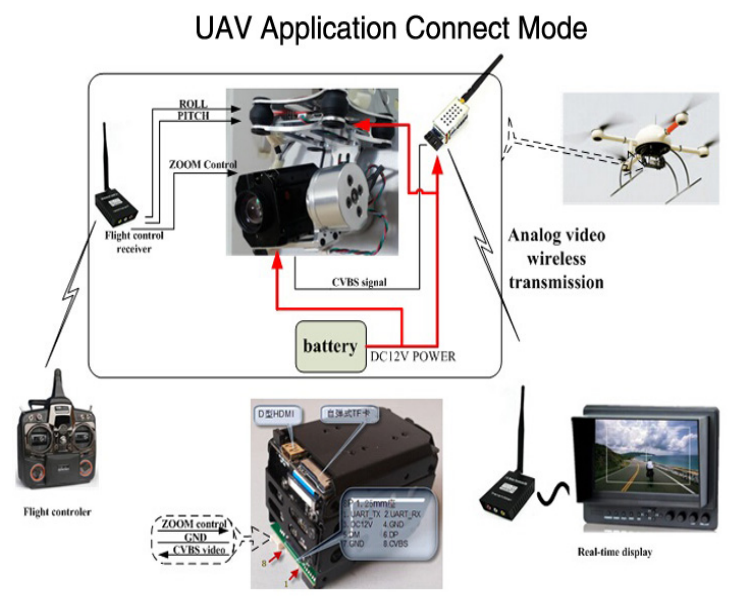

Fig. 4. Camera connections to UAV

Technical systems implemented in the form of optical devices, systems may be placed either directly into the airframe (UAV) and rigidly connected to its structure or via gyrostabilized platform providing the optical axes of rotation of the devices in any direction at a predetermined speed. As a rule, a rigid connection of the optical axis of the device with the aircraft design is used for aircraft cameras and optical viewing devices front or other hemispheres UAV.

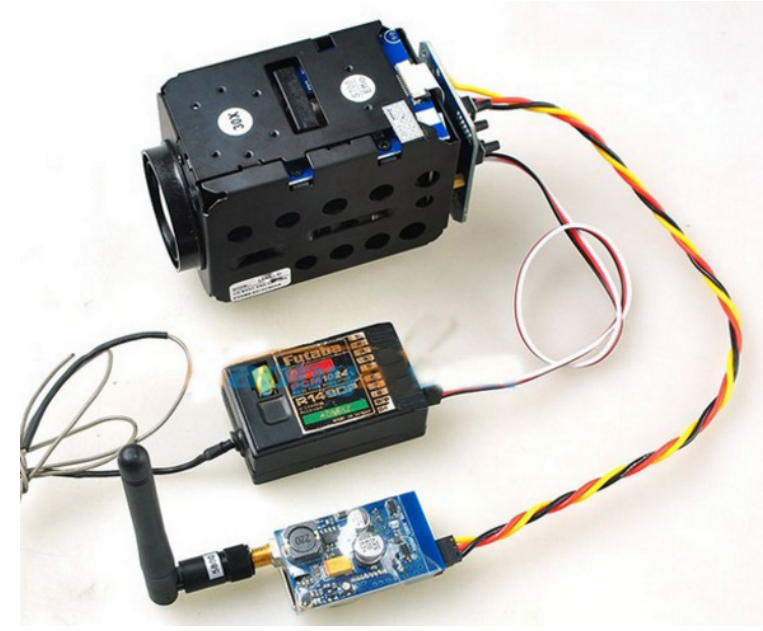

Fig. 5. Camera connection via telemetry

The use of such devices allows us to solve a large number of practical problems, but to get good results you must perform sufficiently stringent requirements to stabilize the position of the aircraft in the air at the time of the shooting. In flight, the stabilization of the front view camera ensures the UAV working off the oscillation of the roll on autopilot signals and data mechanical inertial navigation system. Thus, the video image is stable despite fluctuations in the roll of the UAV. Unfortunately, the principle of the device such units generally does not allow to realize the objectives of tracking mode, and a large number of constraints and difficulties appear when trying to achieve the target tracking mode.

More flexible optical devices are placed on a gyro-stabilized platform (Figs 6 and 7).

The use of gyro-stabilized optical device provides a solution to problems of tracking a selected target with evolutions of aircraft in flight or changing the spatial position of targets.

In this regard, the question arises of equipment selection and estimation of the effectiveness of the installed equipment.

The field of view optical system is an important characteristic, because with its help is provided not only obtaining the desired image of Earth's surface, but also the solution of the problem of the operator of the spatial orientation of the UAV control functions. One of the main criteria for selecting optoelectronic system is its resolution. The main factor determining resolution optoelectronic system is a CCD matrix, which is projected onto the lens when the received an image.

The source of the imagery information is the earth's surface or in its airspace. The angles of the 
field of view of the lens determine the amount of information taken from the earth's surface and airspace, and have a strong influence on the resolution of the device's ability. It should also be borne in mind that the visual information that displayed on the screen is different from the physical content viewing area as a location for color reproduction, and in compliance with the image on the screen the real linear dimensions and outlines of objects on the Earth's surface. The dimensions of the viewport depends on the altitude of the UAV flight, field lens angles of view and the angle of the optical axis of the lens presented on Fig. 8.

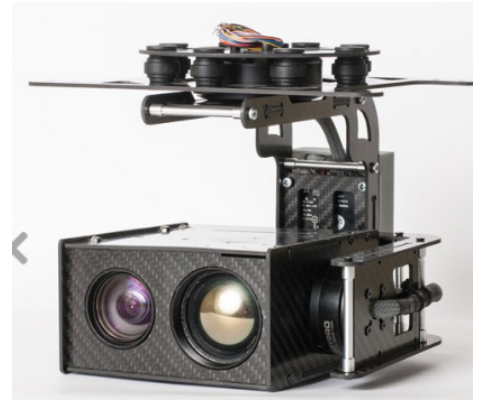

Fig. 6. A camera on gyro-stabilized platform

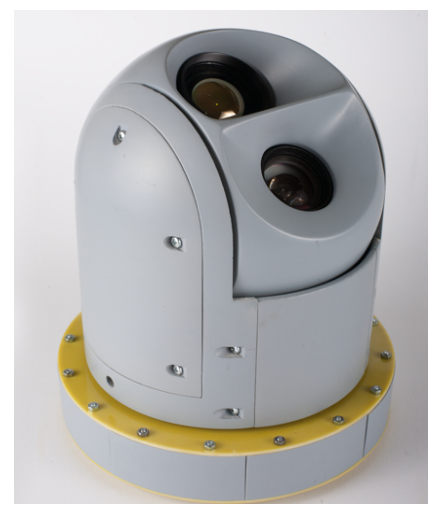

Fig. 7. Another variant of camera on gyro-stabilized platform

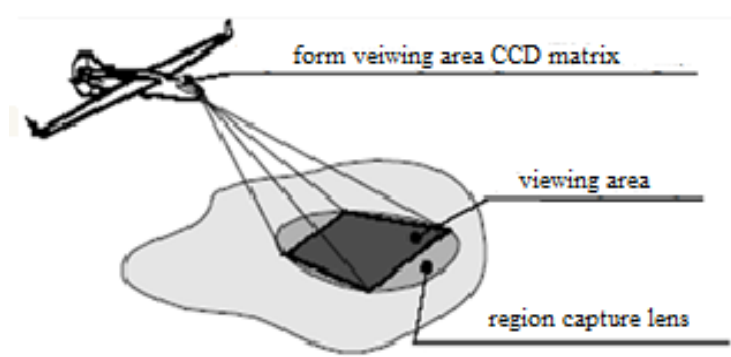

Fig. 8. Field lens angles of view and the angle of the optical axis of the lens

One of the main parameters that allow to define the required altitude, depending on the capabilities of the installed optical system is the fill factor

$$
K_{\text {zap }}=\frac{F_{\text {o. c }}}{F},
$$

where $F_{\text {o.c }}$ is the field area, where is visible target(object); $F$ area of the viewing.

The value inverse to filling factor indicates how many times the need to increase the area of the field of view to the desired object (target) can be seen on the screen of the optical system. The dimension of the matrix CCD has a significant impact on the resolution of the optical device (system), since the dimension of the CCD image sampling determines the level coming from the lens. The higher the dimensionality of the matrix, the higher the sampling rate, and the greater image detail is obtained on display system. Therefore, to get the resolution of the digital optical system, which is close to the optical resolution of the lens power, it is necessary to have, or CCD matrix with very high dimension or to reduce the angles of sight. The resolution of the digital optical system (CCD lens) the display device (screen) is generally defined as dependence of the mean value of the field on-screen resolution of the local group settings:

$$
\bar{R}=f(L, \beta, \gamma, \varphi, M),
$$

where $L$ is the slant range to a point on the earth's surface; $\beta, \gamma, \varphi$, respectively, the angular displacement of the considered point from the optical axis to the right to the left, up and down tilt of the optical axis in the normal coordinate system; $M$ is the dimension of CCD matrix. It is obvious that the dimensions of the CCD screen should not be lower than the CCD matrix.

Structurally optical system with gyrostabilized platform performed such that the lens (or a system of sensors) is provided two axes of rotation relative to the coordinate system associated $O X$ and $O Y$ and angular velocities $\varpi x$ and $\varpi y$. Limit values phi and psi angles of rotation of the lens are usually chosen based on the purpose of the UAV, which will set the optical system, but, as a rule, all-round visibility is provided by $(\psi=00 \ldots 3600$, or $-1900 \ldots+1900)$ and scanning elevation of about $110 \ldots 120$ degrees. Positive values of the angle phi provide viewing and objects tracking located above the axis of the UAV. Such a wide range of angles of deflection of the lens provides a stable support for the object when it is maneuvering or the evolution of the UAV with the optical system.

\section{THE OPTIMAL CHOICE OF OPTICAL SURVEILLANCE DEVICES}

Theoretically the efficiency of the optical system, providing all-round visibility is determined by the conditional probability of detecting an object in the surveyed area. In defining this indicator consider the following conditions: 
- aircraft has a flight speed $V_{\mathrm{loc}}>0$;

- angular rotation speed of the optical axis of the lens $\Omega=\sqrt{\omega_{x}^{2}+\omega_{y}^{2}}$ has limitations. During the simulation system "optical device - operator" so that the angle of the optical axis of the rotation speed can not exceed the value $(0.06 \ldots 0.07) / L$ ( $L$ is the slant range to the center of the viewing area, $m$ );

- angular velocity of rotation of the lens depends on the speed of flight, so it is necessary to take into account the value $V_{\text {loc }}$ and importance of angular UAV speeds with respect to the normal coordinate system when making maneuvers. Otherwise, the operator will see on the screen blurry image. Limitation of angular rotation speed of the optical axis of the lens significantly limits the potential of optoelectronic devices on a gyro-stabilized platform;

- theoretical calculations Foreseeable area is circular and accepted the assumption that the earth's surface in the profile is smooth and close to the surface of a sphere with a radius equal to the radius of the Earth. In reality the earth surface differs considerably from the ideal and all indicators are obtained for an ideal surface is usually worse.

Thus, the problem of the choice of the technical means UAV visual navigation system is to solve the multicriteria problem. Staging multicriteria problems can be formulated as follows:

Of the many $J$ compared samples of optical surveillance systems $\left(j_{k}=\overline{1 ; J}\right)$ specified $k$ th with their intersection $X$ comparable characteristics (indicators) $(x=\overline{1 ; X})$, which describes by integral index of quality (IIQ is necessary to select them according to the criteria of efficiency and cost optimal sample observation optical system Optical Surveillance System OSSjk, the maximum level of the integral index of quality IIQmax and with minimal cost expanses.

Formulate the criteria for selecting optical UAV surveillance devices:

- Accuracy.

- Weight.

- Dimensions.

- Cost.

- Reliability.

- Maintaeance costs.

As an integrated index of quality (IIQ) adopt technical excellence and efficiency of an optical surveillance device. Let us explain this algorithm on the example of selecting the best option out of four samples compared hypothetical observation devices UAV.

The image quality aerial photography is primarily characterized by a resolution of the image, the size of one pixel of the image on the ground. The technical characteristics of modern digital cameras is given focal length equivalent to $35 \mathrm{~mm}$ frame size, and the number of effective pixels of the matrix. The calculation resolution of the image should be made for the pixels farthest from the center of the frame.

Driving connection extreme pixel size picture of the terrain is shown in Fig. 9.

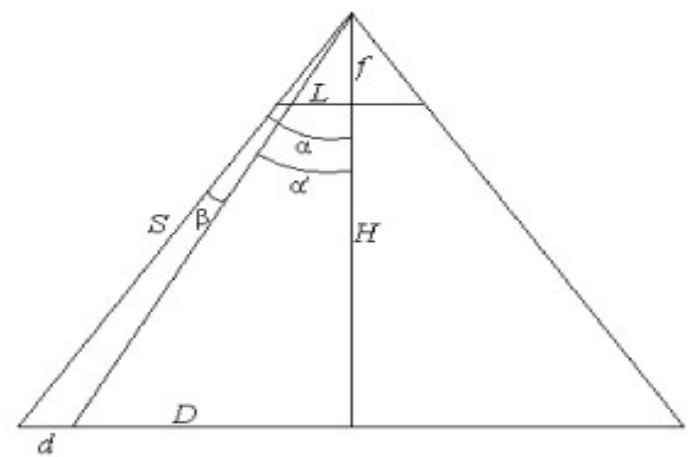

Fig. 9. Driving connection extreme pixel size picture of the terrain: $f$-camera focal length equivalent to $35 \mathrm{~mm}$ frame; $L$ - half the length of the diagonal of a $35 \mathrm{~mm}$ frame, it will be $21.6 \mathrm{~mm} ; H$-altitude during the aerial photography; $D$ - half the length of the diagonal of the image on the ground

The figure shows that when the same value of $L$, expressed in pixels, increasing the value of the focal length will decrease the angle of the camera capture, and the ability to increase image resolution, as one pixel image will have to lower the value of the length of the terrain.

An important parameter of the camera is the physical size of the matrix. The physical size of the matrix and the size of each pixel individually is significantly affect the amount of noise. The larger the physical size of the matrix, the greater its area, and the more light falls on it, resulting in a matrix of the desired signal will be stronger and the signal / noise ratio is better. When a large amount of each pixel isolation layer separating pixels from each other, are thicker and less charge it breaks, and therefore less noise. The matrix of small size because of the small amount of light falling on it, has a weak signal, as a result it is necessary to strengthen, together with the useful signal and noise amplified, which are becoming more visible.

UAVs are divided into classes depending on their weight and size. Aircraft weight category up to $3.5 \mathrm{~kg}$ are not able to raise large-sized professional photographic equipment, therefore, an important parameter of the camera is its weight.

The program to build UAVs visual navigation system aims to reduce the cost on aerial photographs, so that even one of the criteria becomes cameras cost. 
From publicly available information about the camera settings, you can find out the value of the focal length equivalent to $35 \mathrm{~mm}$ film, the physical size of the matrix, the number of effective pixels of the matrix, and the price of the camera. In order to select the optimum camera to a suitable VNS UAVs, we used a multi-criteria optimization method selected multiple cameras lineup of 2008-2009 issue price range of 100 to 485 dollars. Selected cameras with their main characteristics are presented in Table I.

\section{Solution the Problem of Choice} HARDWARE COMPLEXES OF VISUAL NAVIGATION SYSTEM UAV

From publicly available information about the camera settings, you can find out the value of the focal length equivalent to $35 \mathrm{~mm}$ film, the physical size of the matrix, the number of effective pixels of the matrix, and the price of the camera. In order to select the optimum camera to a suitable VNS UAVs, we used a multi-criteria optimization method selected multiple cameras lineup of 2008-2009 issue price range of 100 to 485 dollars. Selected cameras with their main characteristics are presented in Table I.

To calculate the resolution cameras shown in Table I, calculate the half diagonal length, expressed in pixels, each matrix:

$$
L_{\mathrm{px}}=\frac{a^{2}+b^{2}}{2}
$$

where $a$ is the length in pixels of the matrix; $b$ is the width in pixels of the matrix.

Referring to Fig. 9, calculate the angles $\alpha, \beta$ and $\alpha^{\prime}$

$$
\begin{gathered}
\alpha=\operatorname{arcctg} \frac{f}{L} ; \quad \beta=\frac{\alpha}{L_{\mathrm{VNS}}} ; \quad \alpha^{\prime}=\alpha-\beta ; \\
d=H \operatorname{tg} \alpha-H \operatorname{tg} \alpha^{\prime} .
\end{gathered}
$$

According to the equation (2) calculate the size of one pixel on the ground, farthest-foot shot from the center.

The calculation resolution of the selected cameras is shown in Table II, photographing height for all cameras had taken the same $-350 \mathrm{~m}$.

TABLE I

SELECTED CAMERAS WITH THEIR MAIN CHARACTERISTICS

\begin{tabular}{|l|c|c|c|c|c|c|}
\hline \multicolumn{1}{|c|}{ Model } & Price & $\begin{array}{c}\text { Ltnght px } \\
\text { matrix }\end{array}$ & $\begin{array}{c}\text { Widht px } \\
\text { matrix }\end{array}$ & $\begin{array}{c}\text { Matrix } \\
\text { size }\end{array}$ & $\begin{array}{c}\text { F 35 mm } \\
\text { frame }\end{array}$ & Weight \\
\hline Canon IXUS-980IS & $207 \$$ & 4406 & 3312 & $1 / 1.7$ & 36.0 & 160 \\
\hline Lumix DMC-FX150 & $194 \$$ & 4406 & 3312 & $1 / 1.7$ & 28.0 & 154 \\
\hline Lumix DMC-LXj & $294 \$$ & 1648 & 2736 & $1 / 1.6$ & 24.0 & 229 \\
\hline Olympus E-P1 & $445 \$$ & 4032 & 3024 & $1 / 3$ & 34.0 & 385 \\
\hline Pentax Optio A30 & $153 \$$ & 3648 & 2736 & $1 / 1.8$ & 38.0 & 150 \\
\hline Pentax Optio P70 & $320 \$$ & 4000 & 3000 & $1 / 2.3$ & 27.5 & 125 \\
\hline Sony DSC-W200 & $107 \$$ & 4000 & 3000 & $1 / 2.3$ & 29.7 & 146 \\
\hline Sony DSC-W300 & $193 \$$ & 4224 & 3068 & $1 / 1.7$ & 35.0 & 196 \\
\hline
\end{tabular}

TABLE II

THE CALCULATION RESOLUTION OF THE SELECTED CAMERAS

\begin{tabular}{|l|c|c|c|c|c|c|}
\hline \multicolumn{1}{|c|}{ Model } & $L, \mathrm{~mm}$ & $\alpha^{\circ}$ & $L_{\mathrm{VNS}}$ & $\beta,^{\circ}$ & $\alpha^{\prime},{ }^{\circ}$ & $d, \mathrm{~m}$ \\
\hline Canon IXUS-980IS & 21.6 & 31.0027 & 2730 & 0.0114 & 30.9914 & 0.094 \\
\hline Lumix DMC-FX150 & 21.6 & 37.6903 & 2730 & 0.0138 & 37.6763 & 0.135 \\
\hline Lumix DMC-LXj & 21.6 & 42.0311 & 2280 & 0.0184 & 42.0127 & 0.204 \\
\hline Olympus E-P1 & 21.6 & 32.4675 & 2520 & 0.0129 & 32.4546 & 0.111 \\
\hline Pentax Optio A30 & 21.6 & 29.6508 & 2280 & 0.0130 & 29.6397 & 0.105 \\
\hline Pentax Optio P70 & 21.6 & 38.1909 & 2520 & 0.0152 & 38.1758 & 0.150 \\
\hline Sony DSC-W200 & 21.6 & 36.0694 & 2520 & 0.0143 & 36.0551 & 0.134 \\
\hline Sony DSC-W300 & 21.6 & 37.7200 & 2640 & 0.0120 & 31.7080 & 0.101 \\
\hline
\end{tabular}

According to the obtained values of the resolution $d$, for all the cameras were put up balls at the rate of " 1 " point for each decrease of $0.250 \mathrm{~m}$ at $0.005 \mathrm{~m}$. Resolution reflects the combined influence of several factors. Criteria such as location of capture angle, the physical size of the matrix, weight and cost cameras have a slightly smaller value as compared with a resolution. All tests except the resolution, it was decided to evaluate, on a scale. The results of evaluation of cameras shown in Table III.

Table III cells in sorted in descending amount of points. 
TABLE III

RESULTS IN POINTS

\begin{tabular}{|l|c|c|c|c|c|c|}
\hline \multicolumn{1}{|c|}{ Model } & Resolution & Points capture angle & Matrix size & Camera weight & Camera price & Total points \\
\hline Canon IXUS-980IS & 31 & 1 & 2 & 2 & 2 & 38 \\
\hline Lumix DMC-FX150 & 29 & 0 & 2 & 4 & 3 & 38 \\
\hline Lumix DMC-LXj & 30 & 1 & 2 & 2 & 2 & 37 \\
\hline Olympus E-P1 & 23 & 3 & 1 & 4 & 5 & 36 \\
\hline Pentax Optio A30 & 23 & 3 & 2 & 4 & 2 & 34 \\
\hline Pentax Optio P70 & 28 & 1 & 5 & 0 & 0 & 34 \\
\hline Sony DSC-W200 & 20 & 4 & 1 & 5 & 3 & 33 \\
\hline Sony DSC-W300 & 9 & 5 & 3 & 1 & 1 & 19 \\
\hline
\end{tabular}

According to the results of Table III shows that the contact of the selected camera best suited for the purposes of the VNS camera:

\section{Canon IXUS-980IS, Pentax Optio-A3 3 и i sony DSC-W30o,}

Constantly evolving technology to capture the UAV requires the acquisition of new cameras, to select a new camera, this study was conducted.

It should be noted that we have selected cameras are ideal VNS UAV category total weight $4-10 \mathrm{~kg}$. When complex configuration changes and weight category UAV cameras assessment should be reconsidered.

\section{CONCLUSIONS}

1. The goal is an optimal choice UAV attachments for which optimality criteria are defined: the cost, size, precision.
2. In this paper we solve the problem of optimal choice of monitoring devices for UAV based on solving the problem of multicriteria optimization was the use-call of the analytic hierarchy method. Using the proposed approach will improve the efficiency, shorten the time-to design VNS hardware observation for UAV systems and improve the efficiency of their use.

\section{REFERENCES}

[1] V. A. Rogoshyn, V. M. Sineglazov and N. K. Filyashkin, Flight Navigation Complexes of Aircrafts. Kyiv, NAU, 2004, 238 p. (in Ukrainian).

[2] Flight controller Pixhawk http://pixhawk.org

[3] Paul D. Groves, Principles of GNSS, Inertial, and Multisensor Integrated Navigation Systems. Second Edition (Artech House Remote Sensing Library) 2nd Edition, 2008, 503 p.

Received January 18, 2016

Sineglazov Viktor. Doctor of Engineering. Professor.

Aviation Computer-Integrated Complexes Department, National Aviation University, Kyiv, Ukraine.

Education: Kyiv Polytechnic Institute, Kyiv, Ukraine (1973).

Research area: Air Navigation, Air Traffic Control, Identification of Complex Systems, Wind/Solar power plant.

Publications: more than 500 papers.

E-mail:svm@nau.edu.ua

Ischenko Vitaly. Graduade student.

Aviation Computer-Integrated Complexes Department, National Aviation University, Kyiv, Ukraine.

Education: National Aviation University, Kyiv, Ukraine (2015).

Research area: Air Navigation, Embedded systems, Identification of Complex Systems, UAV, Computer Vision.

Publications: 7.

E-mail: IschenkoVitaly@gmail.com

В. М. Синсглазов, В. С. Іщенко. Оптимальний вибір комплексу технічних засобів системи візуальної навігації БПЛА

Розглянуто проблему побудови системи візуальної навігації БПЛА. Запропоновано метод оптимального вибору комплексу технічних засобів системи візуальної навігації на підставі використання методу аналізу ієрархій.

Ключові слова: безпілотний літальний апарат; система візуальної навігації; польотний контролер.

Синєглазов Віктор Михайлович. Доктор технічних наук. Професор.

Кафедра авіаційних комп’ютерно-інтегрованих комплексів, Національний авіаційний університет, Київ, Україна.

Освіта: Київський політехнічний інститут, Київ, Україна (1973). 
Напрям наукової діяльності: аеронавігація, управління повітряним рухом, ідентифікація складних систем, вітроенергетичні установки.

Кількість публікацій: більше 500 наукових робіт.

E-mail:svm@nau.edu.ua

Іщенко Віталій Сергійович. Аспірант.

Кафедра авіаційних комп’ютерно-інтегрованих комплексів, Національний авіаційний університет, Київ, Україна.

Освіта: Національний авіаційний університет, Київ, Україна (2015).

Напрям наукової діяльності: аеронавігація, управління повітряним рухом, ідентифікація складних систем.

Кількість публікацій: 7.

E-mail: IschenkoVitaly@gmail.com

В. М. Синеглазов, В. С. Ищенко. Оптимальный выбор комплекса технических средств системы визуальной навигации БПЛА

Рассмотрена проблема построения системы визуальной навигации БПЛА. Предложен метод оптимального выбора комплекса технических средств системы визуальной навигации на основании использования метода анализа иерархий.

Ключевые слова: беспилотный летательный аппарат; система визуальной навигации; полетный контроллер.

Синеглазов Виктор Михайлович. Доктор технических наук. Профессор.

Кафедра авиационных компьютерно-интегрированных комплексов, Национальный авиационный университет, Киев, Украина.

Образование: Киевский политехнический институт, Киев, Украина (1973).

Направление научной деятельности: аэронавигация, управление воздушным движением, идентификация сложных систем, ветроэнергетические установки.

Количество публикаций: более 500 научных работ.

E-mail:svm@nau.edu.ua

Ищенко Виталий Сергеевич. Аспирант.

Кафедра авиационных компьютерно-интегрированных комплексов, Национальный авиационный университет, Киев, Украина.

Образование: Національний авіаційний університет, Київ, Україна (2015).

Направление научной деятельности: аэронавигация, управление воздушным движением, идентификация сложных систем, встраевыемые системы, автопилоты, компьютерное зрение.

Количество публикаций: 7.

E-mail: IschenkoVitaly@gmail.com 